\title{
Extreme dispersal or human-transport? The enigmatic case of an extralimital freshwater occurrence of a Southern elephant seal from Indiana
}

\author{
Ana M Valenzuela-Toro ${ }^{\text {Corresp., Equal first author, 1,2 }}$, Maria H Zicos ${ }^{\text {Equal first author, 3,4 }}$, Nicholas D Pyenson ${ }^{2,5}$ \\ 1 Department of Ecology and Evolutionary Biology, University of California, Santa Cruz, Santa Cruz, California, United States \\ 2 Department of Paleobiology, National Museum of Natural History, Smithsonian Institution, Washington, D.C., United States \\ 3 School of Biological and Chemical Sciences, Queen Mary University of London, London, United Kingdom \\ 4 Department of Earth Sciences, Natural History Museum, London, United Kingdom \\ 5 Department of Paleontology and Geology, Burke Museum of Natural History and Culture, Seattle, Washington, United States \\ Corresponding Author: Ana M Valenzuela-Toro \\ Email address: anmavale@ucsc.edu
}

Elephant seals (Mirounga spp.) are the largest living pinnipeds, and the spatial scales of their ecology, with dives over $1 \mathrm{~km}$ in depth and foraging trips over 10,000 km long, are unrivalled by their near relatives. Here we report the discovery of an incomplete Holocene age Southern elephant seal ( $M$. leonina) rostrum from Indiana, USA. The surviving material are two casts of the original specimen, which was collected in a construction excavation close to the Wabash River near Lafayette, Indiana. The original specimen was mostly destroyed for radiometric dating analyses in the 1970s, which resulted in an age of $1260 \pm$ 90 years before the present. The existence of sediments in the original specimen suggests some type of post depositional fluvial transportation. The prevalent evidence suggests that this male Southern elephant seal crossed the equator and the Gulf of Mexico, and then entered the Mississippi River system, stranding far upriver in Indiana or adjacent areas, similar to other reported examples of lost marine mammals in freshwater systems. Based on potential cut marks, we cannot exclude human-mediated transportation or scavenging by indigenous peoples as a contributing factor of this occurrence. The material reported here represents by far the northernmost occurrence of a Southern elephant seal in the Northern Hemisphere ever recorded. The unusual occurrence of a top marine predator $>1,000 \mathrm{~km}$ from the closest marine effluent as a potential extreme case of dispersal emphasizes how marine invasions of freshwater systems have happened frequently through historical (and likely geological) time. 
1 Extreme dispersal or human-transport? The enigmatic case of an extralimital freshwater

2 occurrence of a Southern elephant seal from Indiana

3

4 Ana M. Valenzuela-Toro ${ }^{1,2}$, Maria H. Zicos ${ }^{3,4}$, and Nicholas D. Pyenson ${ }^{2,5}$

$5 \quad{ }^{1}$ Department of Ecology and Evolutionary Biology, University of California Santa Cruz, Santa

6 Cruz, California, U.S.A.

72 Department of Paleobiology, National Museum of Natural History, Smithsonian Institution,

8 Washington, DC U.S.A.

$9 \quad{ }^{3}$ School of Biological and Chemical Sciences, Queen Mary University of London, London, U.K.

$10 \quad{ }^{4}$ Earth Sciences Department, Natural History Museum, London, U.K.

$11{ }^{5}$ Department of Paleontology and Geology, Burke Museum of Natural History and Culture,

12 Seattle, WA, U.S.A.

13

14

15

16

17

18

19

20 Corresponding Author:

21 Ana M. Valenzuela-Toro

22130 McAllister Way, Santa Cruz, CA 95060, U.S.A.

23 Email address: anmavale@ucsc.edu 


\section{Abstract}

26 Elephant seals (Mirounga spp.) are the largest living pinnipeds, and the spatial scales of their

27 ecology, with dives over $1 \mathrm{~km}$ in depth and foraging trips over 10,000 km long, are unrivalled by

28 their near relatives. Here we report the discovery of an incomplete Holocene age Southern

29 elephant seal (M. leonina) rostrum from Indiana, USA. The surviving material are two casts of

30 the original specimen, which was collected in a construction excavation close to the Wabash

31 River near Lafayette, Indiana. The original specimen was mostly destroyed for radiometric

32 dating analyses in the 1970 s, which resulted in an age of $1260 \pm 90$ years before the present. The

33 existence of sediments in the original specimen suggests some type of post depositional fluvial

34 transportation. The prevalent evidence suggests that this male Southern elephant seal crossed the

35 equator and the Gulf of Mexico, and then entered the Mississippi River system, stranding far

36 upriver in Indiana or adjacent areas, similar to other reported examples of lost marine mammals

37 in freshwater systems. Based on potential cut marks, we cannot exclude human-mediated

38 transportation or scavenging by indigenous peoples as a contributing factor of this occurrence.

39 The material reported here represents by far the northernmost occurrence of a Southern elephant

40 seal in the Northern Hemisphere ever recorded. The unusual occurrence of a top marine predator

$41>1,000 \mathrm{~km}$ from the closest marine effluent as a potential extreme case of dispersal emphasizes

42 how marine invasions of freshwater systems have happened frequently through historical (and

43 likely geological) time. 
44

45

46

47

48

49

50

51

52

53

54

55

\section{Introduction}

Elephant seals (Mirounga spp. Gray, 1827) are the largest living pinnipeds, and the spatial scale of their ecology are equally unrivalled among marine mammals: they routinely dive to over $1 \mathrm{~km}$ in depth - occasionally over $2 \mathrm{~km}$ in depth - and their foraging trips may reach more than 10,000 km (Le Boeuf et al., 2000; Robinson et al., 2012; Hindell et al., 2016). Both species in the genus Mirounga, the Northern elephant seals (Mirounga angustirostris Gill, 1866) and the Southern elephant seals (Mirounga leonina Linnaeus, 1758), show a broadly anti-tropical distribution in the Northern and Southern hemispheres, respectively (Hindell, 2018; Davies, 1958). The specific localities of rookeries for each species have shifted since they were first studied, which has prompted the suggestion that their current geographic range is largely a result of centuries or millennia of human hunting that extirpated previously occupied ranges (Rick et al., 2011). Regardless, Northern elephant seals have largely recovered from near extinction in the late 19th century, with breeding colonies in California and Mexico. Nonetheless, it is unclear whether the same is true for Southern elephant seals, whose colonies are located in southernmost Argentina and Chile and on island archipelagos throughout the Southern Ocean (Davies, 1958;

McMahon et al., 2005).

Besides routine long-distance foraging, elephant seals have been recorded outside the geographic limits of their known foraging range (e.g., Elorriaga-Verplancken et al., 2020). Extralimital sightings include records of Northern elephant seals in Japan and Hawaii (Reeves et al. 2002); similarly, Southern elephant seals have been sighted along the coast of Brazil in the South Atlantic, the coast of Oman in the Indian Ocean, and even the Gulf of California in the Northern Hemisphere (Elorriaga-Verplancken et al., 2020; Johnson, 1990; Mayorga et al., 2017). Here we 
67 report the surprising discovery of an archaeological occurrence of Mirounga leonina represented

68 by an incomplete rostrum that is Holocene age (1260 \pm 90 radiocarbon years before present, BP),

69 recovered from the banks of the Wabash River near Lafayette, Indiana, USA. This find, located

70 along a major river that drains most of Indiana's watershed to the Ohio River and then to the

71 Mississippi River, is also an unusual occurrence for elephant seals because it is located

72 approximately $1,400 \mathrm{~km}$ inland in a freshwater river system.

\section{Materials and Methods}

75

(i) Institutional Abbreviations-FMNH, Geological Collections, Field Museum of Natural History, Chicago, Illinois, USA; LACM, Department of Mammalogy, Natural History Museum of Los Angeles County, Los Angeles, California, USA; USNM, Departments of Paleobiology and Vertebrate Zoology (Division of Mammals), National Museum of Natural History, Smithsonian Institution, Washington, District of Columbia, USA.

(ii) Material-USNM 375734 is a cast in the Smithsonian Institution's Department of

Paleobiology. The original specimen consisted of a nearly complete right maxilla with the canine in situ but lacking the postcanine dentition (figure 1a-f). The original specimen was fortuitously found and collected during a building excavation in 1965, approximately 9 meters below the surface of the riverbanks of the Wabash River near Lafayette, Indiana, USA $\left(40^{\circ} 25^{\prime} \mathrm{N}, 86^{\circ} 54^{\prime} \mathrm{W}\right.$; figure 2b). Archival notes and correspondence housed at FMNH indicate that the bone of the original specimen was "not replaced, and therefore looks to be recent [sic] and not fossil" (C. E. Ray to W. D. Turnbull, personal communication; see electronic supplementary material file S1). Further, this documentation identifies that the original specimen had "some black pebbles and sand occluding one alveolus (potentially P1) and some small nutrient foramina" (page 11, 
90 electronic supplementary material file S1), which are indicative of intermediate or relatively high

91 ambient current energy, suggesting that the specimen underwent some type of post-mortem river

92 transportation (Behrensmeyer, 1982; Brett and Baird, 1986). Unfortunately, the original

93 specimen was almost completely destroyed for ${ }^{14} \mathrm{C}$ dating analyses in the 1970 s, and only a few

94 milligrams of the original bone remains at the FMNH. The conventional radiocarbon age (1260 \pm

9590 radiocarbon years BP; laboratory number Tx-1651, University of Texas at Austin; Valastro et

96 al., 1988) places the specimen as Late Holocene in age, prior to European contact and settlement

97 of the Americas (see further discussion about radiometric measurements in electronic

98 supplementary text S1). Two plaster casts of the original specimen remain: PM 37625 at the

99 FMNH and USNM 375734 at the Smithsonian Institution. Morphological descriptions herein

100 were derived from USNM 375734. In addition, cast PM 37625 was evaluated by one of the

101 authors (MZ) confirming that its morphology is indistinguishable from USNM 375734.

102 (iii) Specimens observed-Mirounga leonina (USNM 239141, 241199, 484893, 504927), and

103 Mirounga angustirostris (USNM 21738, 21890, 38234, 260867, 265353, 267987, 14929, 15270,

104 20927, 21886, 21896, 200953, 219058, LACM 54394), Mirounga sp. indeterminate (USNM

105 55079).

106 3. Results

107 (i) Morphological description-USNM 375734 consists of a cast of a nearly complete right

108 maxilla. Measurements of the specimen are provided in Table 1. The right canine is complete.

109 The alveoli for P1-P4 and M1 are oval to sub-oval in shape, single-rooted and anteriorly

110 oriented. The anterior portion of the maxilla is well preserved. The lateral surface of the maxilla

111 is pocketed by tiny $(<1 \mathrm{~mm})$ foramina between the infraorbital foramen and the canine, which is

112 a surface texture that resembles physically mature specimens of male elephant seals (e.g., USNM 
113 260867, 484893). In dorsal view, and posterior to the level of P4, much of the margin of the

114 maxilla appears to be missing and worn (potentially associated to some type of post-mortem

115 transportation), exposing the inner pocketing of the external bony nares. In lateral view, the

116 dorsal profile of the maxilla is steep in the posteriormost portion $\left(\sim 50^{\circ}\right.$ at the level of the alveoli

117 of M1 and P4), then anteriorly flatter $\left(20^{\circ}\right)$ until the position level with the posterior edge of the

118 alveolus of $\mathrm{P} 1$, where the angle becomes intermediate before finally curving around the alveolus

119 of the canine. The infraorbital foramen is dorsoventrally compressed (measuring $\sim 20 \mathrm{~mm}$ in

120 diameter in the widest orientation and $\sim 15 \mathrm{~mm}$ in height), and it is visible in lateral, anterior and

121 oblique ventral views. The base of the zygomatic process of the maxilla is robust and rugose in

122 its inner surface. The preorbital (= infraorbital) process of the maxilla is conspicuous, though

123 slightly worn, and it is located $\sim 2 \mathrm{~cm}$ dorsal of the base of the zygomatic process. Together,

124 these two structures underlie an apparent large and elevated orbit (i.e., situated above the level of

125 the alveoli row). In ventral view, the posterior border of the maxilla is semi-circular, and

126 potentially constitutes the joint line between the maxilla and the palatine. USNM 375734 likely

127 represents a physically mature individual because of its large size, the lateral surface texture, the

128 relatively static position of the canine in its alveolus, and the possession of clear interalveolar

129 septa between the postcanine alveoli. Furthermore, USNM 375734 likely represents a male based

130 on qualitative and quantitative comparisons (see figure 3).

131 USNM 375734 exhibits a semi-linear striation transversally directed in the dorsolateral

132 surface of the maxilla that is approximately $2 \mathrm{~cm}$ long (figure 4). In addition, three fine semi-

133 parallel striae ( $\sim 2 \mathrm{~cm}$ long) occur in the medial section of the maxilla, which align with the

134 major striation described above. The narrow, shallow and linear aspect, together with the parallel

135 distribution of the striae suggest that they would correspond to intentional cuts by a sharp-edged 
136 implement (e.g., stone tool, but not a metal tool) (Fisher, 1995; Greenfield, 2006; Domínguez-

137 Rodrigo and Baquedano, 2018). However, the loss of the original specimen prevents us from

138 performing a more detailed examination of these striae (e.g., scanning electronic microscopy).

139 (ii) Remarks - USNM 375734 belongs to Phocidae, based on the anterior extension of the

140 rostrum relative to both the (inferred) position of the nasals, and the position of the bony naris, as

141 well as the relatively large size of the infraorbital foramen. Additionally, USNM 375734 belongs

142 to Mirounga based on: a combination of an overall large size with an enlarged canine tooth; its

143 toothrow anteriorly oriented; and the possession of single-rooted postcanine alveoli (King,

144 1972). The principal osteological differences between M. angustirostris and M. leonina relate to

145 traits associated with the elongation of the rostrum and morphology in the ventral surface of the

146 skull (Briggs and Morejohn, 1976). M. leonina has a foreshortened skull compared to $M$.

147 angustirostris, which is reflected in differences in the relative position and elongation of

148 different structures in the anterior section of the rostrum. For instance, the position of the last

149 molar with respect to the level of the infraorbital foramen constitutes a diagnostic trait to

150 differentiate between the species, with M. leonina having M1 located at the same level as the

151 infraorbital foramen, whereas $M$. angustirostris has it located anteriorly to this level (Briggs and

152 Morejohn, 1976). In this regard, USNM 375734 mirrors the morphology of M. leonina in having

153 the alveolus of M1 aligned with the infraorbital foramen. Furthermore, the dorsal aspect of the

154 anterior section of the maxilla, where it contacts the premaxilla, is anteroposteriorly short and

155 has a transversely oriented posterior margin, giving it a relatively square appearance, parallel to

156 M. leonina, and contrasting with M. angustirostris, in which this margin is oriented

157 posterolaterally and has a more rectangular shape. The shape of the dorsal profile of the maxilla

158 (i.e., steep in the posteriormost portion, then anteriorly flat, and then curving around the alveolus 
159 of the canine) also contrasts with adult male M. angustirostris, in which the dorsal aspect is steep

160 but straight (e.g., USNM 219058 in the Division of Mammals, and LACM 54394).

161 Unfortunately, other diagnostic traits could not be evaluated because of the fragmentary nature of

162 the specimen reported here. However, we consider that the relative position of the alveolus of

163 M1 relative to the infraorbital foramen, the orientation and shape of the contact between the

164 premaxilla and the maxilla, and the dorsal aspect of the maxilla as the most salient comparative

165 traits, and they support our differential diagnosis and identification of USNM 375734 as a

166 Southern elephant seal.

167 (vi) Radiocarbon date - The radiocarbon measurement Tx-1651 (Valastro et al. 1988) was

168 collected prior to this study, in 1972 or 1973, using a laboratory at the University of Texas at

169 Austin (FMNH archives; see electronic supplementary material file S1). This laboratory used

170 liquid scintillation counting of benzene with lithium carbide and vanadium catalysts; they

171 obtained the conventional date of $1260 \pm 90 \mathrm{yrs}$ BP from the apatite portion of the bone, reported

172 with $1 \sigma$. Their calculation was based on ${ }^{14} \mathrm{C}$ half-life of 5568 years and "modern standard of $95 \%$

173 NBS oxalic acid, supplemented by tree rings of pre-industrial wood from a log cut in the 1850 s"

174 (Tx-540; see Valastro and Davis 1970; Valastro et al. 1988). Although no pre-treatment is

175 mentioned in the date list, the laboratory followed Haynes (1968)'s acid pre-treatment of apatite

176 in previously measured bones (Valastro and Davis 1970); we infer that the original specimen

177 may have been similarly pre-treated. No value for the organic or collagen portion of the bone

178 was reported; we thus assume that these analyses were not undertaken at the time. Lastly,

179 Valastro et al. (1988) state that no measurements of ${ }^{12} \mathrm{C}$ or ${ }^{13} \mathrm{C}$ were collected, and that no

180 corrections were made for fractionation of ${ }^{13} \mathrm{C}$ (Valastro et al. 1988).

181 
182

183

184

185

186

187

\section{Discussion}

Living Southern elephant seals have a nearly circumpolar distribution in the Southern Hemisphere with breeding colonies in the southernmost part of Chile and Argentina and SubAntarctic islands. We argue that the preponderance of evidence suggests that USNM 375734 represents an adult male Southern elephant seal, which was an errant migrant that swam northward from the South American coast into the Mississippi River system via the Gulf of Mexico, and eventually stranded upriver in Indiana where it was killed or scavenged by indigenous peoples. We base our interpretations on the combination of biological and life history, and physical evidence as follows.

First, Southern elephant seals are capable of performing long foraging migrations that can extend several thousand of kilometres, spending, on average, almost 10 months of the year at sea (Hindell and McMahon, 2000; Hindell et al., 2016). In fact, extralimital occurrences at very distant locations from their known distribution are not uncommon (see below). Moreover, the occurrence of oceanographic events affecting the prey distribution (e.g., La Niña cold conditions) have been suggested as key factors driving these abnormal occurrences along the South Pacific and Atlantic oceans (see Elorriaga-Verplancken et al., 2020). Second, the radiometric age of the specimen is contemporaneous in time ( 1200 years BP) with native Mississippian civilizations, including the Cahokia culture that inhabited the Mississippi River region between $\sim 700-1400$ of the Current Era (Pauketat, 2004). While radiocarbon dates obtained from the original bone (and in particular, apatite) from the early 1970s are considered unreliable due to a combination of technological and methodological concerns (see ESM), there is no way to resample the original specimen (see below); also, we note that marine mammal material is especially susceptible to the marine reservoir effect, which biases radiocarbon dates 
205 towards older values (Stuiver and Polach, 1977). The original analysis did not correct the

206 conventional date for the marine reservoir effect, but corrections for marine mammal material

207 have reduced the conventional (uncalibrated) age from 200 years and younger to upwards of 800

208 years, depending on the local magnitude of the reservoir effect (e.g., Dyke et al., 1996; Koch et

209 al., 2019; Olsson, 1980); by implication, the original specimen may be several hundred years

210 younger than $\sim 1200$ years BP. Third, the presence of potential intentional cuts marks by some

211 type of stone tool (see figure 4) prevents us from excluding some degree of human-mediated

212 transportation. Unfortunately, the absence of original skeletal material precludes more exhaustive

213 interpretation and study of these marks. Furthermore, the complete lack of carnivore scavenging

214 marks suggests a short post-mortem period before burial for this individual; yet, the existence of

215 sediment (i.e., pebble and sand) occluding one alveolus indicates that the specimen underwent

216 some type of post-depositional fluvial transportation, likely in Indiana (although we cannot

217 exclude the possibility of elsewhere).

218 Another, and less likely explanation, is that the skull was collected by indigenous peoples

219 along the coast of South America or at an intermediate point (including the Mississippi drainage

220 or coastal Americas), and then transported (singularly in one lifetime, or across a trade route)

221 until its deposition on the banks of the Wabash River. In this regard, Mississippian societies were

222 characterized by long distance trading networks of several goods, principally mineral resources

223 like galena, copper, and salt, as well as marine shells which had high socioeconomic importance

224 (Prentice, 1987; Trubitt, 2005). Furthermore, the archaeological record indicates that only

225 skeletal elements of high socioeconomic value (e.g., isolated canines) would likely be

226 transported long distances and traded by indigenous people in the Americas (Lyman, 1994). We

227 thus judge this potential scenario as less likely of an explanation than a basic biological one. 
Although the morphological evidence strongly supports our identification of USNM

229

230

231

232

233

234

235

236

237

238

239

240

241

242

243

244

245

246

247

248

249

375734 as a male Southern elephant seal, it should be noted that its correspondence to a Northern

elephant seal cannot be entirely excluded. Considering that their current and historical range is

delimited to the eastern current systems of the North Pacific Ocean and its coastlines, the

potential finding of a male Northern elephant seal in Indiana could be explained through two

non-exclusive scenarios. For one, an individual could have swum northward along the western

coast of North America, reaching the Arctic, and then crossing the Arctic to the Atlantic.

Breeding colonies of Northern elephant seals are located along the Californian coast up to

Mexico; however, male individuals perform long distance post breeding foraging migrations,

reaching the coast of Alaska and the Aleutian Islands, and even of Japan and Russia (Le Boeuf et al., 2000; Fomin and Burkanov, 2019). Thus, an errant male could have transited along the northernmost border of North America through the Arctic reaching the North Atlantic Ocean, to finally enter into a river system via the Gulf of St. Lawrence or the Gulf of Mexico, where it could it be killed or scavenged by indigenous peoples. Nevertheless, we consider this scenario unlikely because there are no records of this type of dispersal (i.e., throughout the Arctic) for elephant seals. Secondly, a male Northern elephant seal could have been killed or scavenged by indigenous peoples somewhere on the western coast of North America and then transported and/or traded into the Mississippi River region. If this is the case, we would expect to find similar archaeological or historical records of marine mammal fauna from the North Pacific in the Mississippi Region; however, we did not find previous reports supporting this hypothesis. Furthermore, Rick et al. (2011) have suggested that during much of the Holocene, the abundance and distribution of Northern elephant seals along the western coast of North America were 
250 different than today, being characterized by a low abundance along the coast of California,

251 reducing the likelihood of this scenario even more.

252 Molecular methods to confirm or refine the taxonomic identifications, such as ancient

253 DNA or collagen fingerprinting, were not applied because the surviving material of the original

254 specimen at FMNH is insufficient for analysis. This material is unlikely to yield results; or, at

255 best, unlikely to yield results that would enhance our morphological assessment. First, it is

256 unknown whether the original bone was well preserved and likely to yield DNA or collagen.

257 Second, the remaining material consists of a few milligrams of bone chips and small gravel,

258 probably from the external part of the bone, which is usually removed during sampling for DNA

259 (e.g., Brace et al., 2012; Frantz et al., 2016; Rohland and Hofreiter, 2007). This material is far

260 less than the ideal minimum of $10-20 \mathrm{mg}$ of bone powder obtained from dense bone after

261 contamination-removal methods (Dabney and Meyer, 2019), suggesting that the surviving bone

262 fragments of the original specimen are very unlikely to yield endogenous DNA or collagen.

263 Collagen fingerprinting, based on spectroscopy of collagen, has been conducted on both $M$.

264 angustirostris and M. leonina, and their collagen spectra appear indistinguishable (Hofman et al.,

265 2018). These latter concerns, even if sufficient material from the original specimen were

266 available, mitigate against the utility of these techniques to advance with the taxonomic

267 identification in this case.

268 Interestingly, the historical record provides many accounts for extralimital records in

269 pinnipeds. For instance, hooded seals (Cystophora cristata (Erxleben, 1777)), native to North

270 Atlantic and polar waters, have been recorded as far south as the Caribbean (Mignucci-Giannoni

271 and Odell, 2001) and the Pacific Ocean (Dudley, 1992). Similarly, Antarctic seals such as

272 Weddell seals (Leptonychotes weddellii (Lesson, 1826)) have been recorded off the coast of 
273 Brazil (Frainer et al., 2018) and New Zealand (Miskelly, 2015). Tropical species also have

274 vagrant individuals, as it is shown by a record of a Galapagos fur seal (Arctocephalus

275 galapagoensis Heller, 1904) in Guatemala (Quintana-Rizzo et al., 2017). In particular, vagrant

276 Southern elephant seals have been recorded on the coasts of Argentina, Uruguay, Brazil, Chile,

277 Peru, Ecuador, Galapagos Islands, Panama, South Africa, Australia, New Zealand, Oman, and

278 Mexico (figure 2a) (Alava and Carvajal, 2005; Magalhães et al., 2003; Mayorga et al., 2017;

279 Redwood and Felix, 2018; Acevedo et al., 2016; Johnson, 1990; Sepúlveda et al., 2007; de

280 Moura et al., 2010; Pacheco et al., 2014; Cárcamo et al., 2019; Sepúlveda et al., 2018; de Moura

281 et al., 2011; Mertz and Bester, 2011; Mayorga et al., 2016; Shaughnessy et al., 2012; Elorriaga-

282 Verplancken et al., 2020).

283 Nevertheless, the material reported here represents by far the northernmost occurrence of

284 a Southern elephant seal in the Northern Hemisphere, and potentially the most extreme

285 freshwater incursion of a marine pinniped ever recorded. Notably, inland Holocene marine

286 mammal localities have previously been reported across the USA, including Holocene and

287 Pleistocene age manatee (Trichechus manatus Linnaeus, 1758) material from the Ohio and

288 Mississippi rivers (Williams and Domning, 2004; Baghai-Riding et al., 2017), although these

289 finds are consistent with routine freshwater incursions that manatees often undertake. More

290 strikingly, Holocene age bowhead (Balaena mysticetus Linnaeus, 1758), rorqual

291 (Balaenopteridae sensu lato) and sperm whale (Physeter macrocephalus Linnaeus, 1758)

292 material have been reported from Michigan (Harington, 1988). Although Harington (1988)

293 considered each occurrence to have been human-mediated transport, elsewhere in North America

294 Pleistocene and Holocene cetacean material is not uncommon, especially, adjacent to large river

295 drainages (Harington, 1988). Prehistoric harbor seals (Phoca vitulina Linnaeus, 1758) have been 
296 reported along the Columbia River of Washington State (USA), at a maximum of $\sim 300 \mathrm{~km}$

297 upriver from the closest marine effluent source (Lyman et al., 2002). However, these are shorter

298 distances than the putative one for the Indiana specimen $(\sim 1,400 \mathrm{~km})$. While the incursions of

299 Columbia River harbor seals were likely limited by waterfalls (Lyman et al., 2002), the

300 incursions represented by manatee material from Ohio (Williams and Domning 2004), a

301 common bottlenose dolphin from Tennessee (J. G. Mead, pers. comm.) indicate that there is no

302 obvious physical barrier for marine mammals to make long-distance upriver incursions in those

303 rivers (including the Wabash River), at least in the Holocene, and likely in the Pleistocene as

304 well. Further, the record of vagrant elephant seals from the Guayas River Estuary Basin (Gulf of

305 Guayaquil) in Ecuador implies an extralimital dispersion over a geographic range of $\sim 8000 \mathrm{~km}$

306 from the circumpolar region to tropical freshwater systems in the Gulf of Guayaquil (Páez-Rosas

307 et al., 2018). These confirmed sightings were made upwards of $50 \mathrm{~km}$ in the river system, and

308 animals were not in poor body condition (Páez-Rosas et al., 2018), meaning that Southern

309 elephant seals can travel upriver with no serious detrimental effects to their health. This latter

310 occurrence, and the fact that other phocids use freshwater habitats (e.g., harbor seals in Canada

311 and Lake Saima ringed seal Pusa hispida saimensis (Nordquist, 1899), suggests an absence of

312 physiological restrictions for seals moving upriver as well.

313 Departures from routine dispersal or migratory patterns in marine mammals, including

314 Southern elephant seals, are surprising but not uncommon (e.g., Lyman et al., 2002; Lucero et

315 al., 2018; Geijer et al., 2016; Weller et al., 1996, Elorriaga-Verplancken et al., 2020). In this

316 study, the occurrence of a top marine predator at more than $1,000 \mathrm{~km}$ from the closest marine

317 effluent source shows that the dispersal behavior of elephant seals is more dynamic and complex

318 than previously recognized, suggesting a reconsideration of the current assumptions of elephant 
319 seal (as well as other marine mammals) life history patterns. Many questions arise from this

320 finding, including the evolutionary and conservation implications of these extreme dispersal

321 behaviors: is this behavioral plasticity partially responsible for the ongoing population recovery

322 and recolonization of elephant seals after their near extermination during the last century? Could

323 this dispersal ability make elephant seals more resilient to oceanographic and ecological changes

324 resulting from climate change? Ultimately, advances in telemetry techniques, stable isotope

325 analysis, and ancient DNA will provide critical information for a better understanding of these

326 enigmatic long dispersals of top marine predators (Harcourt et al., 2019; Pinsky et al., 2010).

327

\section{5. Conclusions}

We presented the finding of a cast of a Holocene rostrum of a Southern elephant seal

330 (Mirounga leonina) from Indiana, USA. The radiometric dating of the original specimen prior to

331 this study resulted in a conventional age of $1260 \pm 90$ years before the present. The specimen

332 was identified as an adult male Southern elephant seal based on the size of the canine, the

333 relative position of the alveolus of M1 relative to the infraorbital foramen, the orientation and

334 shape of the contact between the premaxilla and the maxilla, and the dorsal aspect and lateral

335 surface texture of the maxilla. Considering the natural history and ecology of modern Southern

336 elephant seals, we propose that this adult male crossed the equator and the Gulf of Mexico, and

337 entered the Mississippi River system, stranding far upriver in Indiana or adjacent areas.

338 Nevertheless, because of the occurrence of potential cut marks, we cannot exclude human-

339 mediated transportation or scavenging by indigenous peoples as a contributing factor to this

340 occurrence. This record represents the northernmost occurrence of a Southern elephant seal ever 
341 recorded and suggest that invasions of freshwater systems by marine mammals have happened

342 frequently through time.

343

344 Ethics statement. No ethical assessments were required to conduct this research. No fieldwork

345 was conducted by the authors for this project.

346 Data accessibility. Additional data are in the electronic supplementary material.

347 Author contributions. Maria H. Zicos and Nicholas D. Pyenson designed the research. Maria H.

348 Zicos, Nicholas D. Pyenson, and Ana M. Valenzuela-Toro photographed, measured, described

349 the specimens, analyzed the data and wrote the paper.

350 Acknowledgments. We are thankful to P. Koch, D. Costa, T. Keates, A. Favilla, T. Rick, B.

351 Pobiner, and E. G. Veatch for comments that improved early versions of this study. Finally, we

352 thank the editor and two anonymous reviewers whose comments significantly improved this

353 manuscript.

354

355

356 Acevedo J, Aguayo-Lobo A, Brito JL, Torres D, Cáceres B, Vila A, Cardeña M, Acuña P. 2016.

357 Review of the current distribution of southern elephant seals in the eastern South

358 Pacific. New Zealand Journal of Marine and Freshwater Research 50, 240-258. (doi:

359

$10.1080 / 00288330.2015 .1132746)$

360 Alava JJ, Carvajal R. 2005. First records of elephant seals on the Guayaquil Gulf, Ecuador: on

361 the occurrence of either a Mirounga leonina or M. angustirostris. Latin American Journal of

362 Aquatic Mammals 4, 195-198. (doi: 10.5597/lajam00086) 
363 Baghai-Riding NL, Husley DB, Beck C, Blackwell E. 2017. Late Pleistocene megafauna from

364 Mississippi alluvium plain gravel bars. Paludicola 11, 124-147.

365 Behrensmeyer AK. 1982. Time resolution in fluvial vertebrate assemblages. Paleobiology 8,

366 211-227. (doi: 10.1017/S0094837300006941)

367 Brace S, Palkopoulou E, Dalén L, Lister AM, Miller R, Otte M, Germonpré M, Blockley SPE,

368 Stewart JR, Barnes I. 2012. Serial population extinctions in a small mammal indicate Late

369 Pleistocene ecosystem instability. Proceedings of the National Academy of Sciences 109,

370 20532-20536. (doi: 10.1073/pnas.1213322109)

371 Brett CE and Baird GC. 1986. Comparative taphonomy: a key to paleoenvironmental

372 interpretation based on fossil preservation. Palaios, pp.207-227.

373 Briggs KT, Morejohn GV. 1976. Dentition, cranial morphology and evolution in elephant seals.

$374 \quad$ Mammalia 40, 199-222.

375 Cárcamo D, Pizarro M, Orellana M, Muñoz L, Pavez G, Sepúlveda M, Durán LR, Oliva D.

376 2019. Are southern elephant seals re-invading mid-latitude grounds? New sightings and first

377 birth records off the Chilean Coast. Polar Biology 42, 433-440. (doi: 10.1007/s00300-018-

$378 \quad 2433-z)$

379 Dabney J, Meyer M. 2019. Extraction of Highly Degraded DNA from Ancient Bones and Teeth 380 in: Ancient DNA: Methods and Protocols, Methods in Molecular Biology 1963, 25-29. (doi:

$\left.381 \quad 10.1007 / 978-1-4939-9176-1 \_4\right)$

382 Davies JL. 1958. The Pinnipedia: an essay in zoogeography. Geographical Review 48, 474-493. $383 \quad$ (doi: $10.2307 / 211670)$ 
384 de Moura JF, di Dario BPS, Lima LM, Siciliano S. 2010 Southern elephant seals (Mirounga

385 leonina) along the Brazilian coast: review and additional records. Marine Biodiversity

$386 \quad$ Records 3, e18. (doi: 10.1017/s1755267209991138)

387 de Moura JF, di Dario BPS, Siciliano S. 2011. Occurrence of pinnipeds on the coast of Rio de

388 Janeiro State, Brazil. Marine Biodiversity Records 4, e27. (doi:

$389 \quad 10.1017 / \mathrm{S} 1755267211000030)$

390 Domínguez-Rodrigo M, Baquedano E. 2018. Distinguishing butchery cut marks from crocodile

391 bite marks through machine learning methods. Scientific reports $\mathbf{8}, 1-8$. (doi:

$392 \quad 10.1038 / \mathrm{s} 41598-018-24071-1)$

393 Dudley M. 1992. First Pacific record of a hooded seal, Cystophora cristata Erxleben,

394 1777. Marine mammal science 8, 164-168. (doi: 10.1111/j.1748-7692.1992.tb00377.x)

395 Dyke AS, McNeely RN, Hooper J. 1996. Marine reservoir corrections for bowhead whale

396 radiocarbon age determinations. Canadian Journal of Earth Sciences 33, 1628-1637 (doi:

$397 \quad \underline{10.1139 / \mathrm{e} 96-123})$

398 Elorriaga-Verplancken FR, Blanco-Jarvio A, Silva-Segundo CA, Paniagua-Mendoza A, Rosales-

399 Nanduca H, Robles-Hernández R, Mote-Herrera S, Amador-Capitanachi MJ, Sandoval-

400 Sierra J. 2020. A Southern Elephant Seal (Mirounga leonina) in the Gulf of California:

401 Genetic Confirmation of the Northernmost Record to Date. Aquatic Mammals 46, 137-145

$402 \quad$ (doi: 10.1578/AM.46.2.2020.137)

403 Erxleben JCP. 1777. Systema regni animalis per classes, ordines, genera, species, varietates :

404 cvm synonymia et historia animalivm: Classis I. Mammalia. 636pp.

405 Fisher JW. 1995. Bone surface modifications in zooarchaeology. Journal of Archaeological

406 method and theory 2, 7-68. 
407 Fomin SV, Burkanov VN. 2019. Records of Northern Elephant Seals, Mirounga angustirostris 408 Gill, 1866 (Mammalia: Phocidae), from the Kuril Islands. Russian Journal of Marine Biology 45, 330-332. (doi: 10.1134/S1063074019040060)

410 Frainer G, Heissler VL, Moreno IB. 2018. A wandering Weddell seal (Leptonychotes weddellii) 411 at Trindade Island, Brazil: the extreme sighting of a circumpolar species. Polar Biology 41, 412 579-582. (doi: 10.1007/s00300-017-2218-9)

413 Frantz LAF, Mullin, VE, Pionnier-Capitan M, Lebrasseur O, Ollivier M, Perri A, Linderholm A, 414 Mattiangeli V, Teasdale, MD, Dimopoulos, EA, Tresset A, Duffraisse M, McCormick F, 415 Bartoziewicz L, Gál E, Nyerges EA, Sablin MV, Bréhard S, Mashkour M, Bălăşescu A, 416 Gillet B, Hughes S, Chassaing O, Hitte C, Vigne J-D, Dobney K, Hänni K, Bradley DG, 417 Larson G. 2016. Genomic and archaeological evidence suggests a dual origin of domestic dogs. Science 352, 1228-1231. (doi: 10.1126/science.aaf3161)

419 Geijer CK, Notarbartolo di Sciara G, Panigada S. 2016. Mysticete migration revisited: are 420 Mediterranean fin whales an anomaly?. Mammal Review 46, 284-296. (doi: 10.1111/mam.12069)

422

423

424 425 426 427 428

Gill T. 1866. On a new species of the genus Macrorhinus. Proceedings Chicago Academy of Sciences 1, 33-34.

Gray JE. 1827. A synopsis of the species of the class Mammalia. Vol. 5, 392 pp., in The animal kingdom arranged in conformity with its organization, by the Baron Cuvier, member of the Institute of France, \&c \&c \&c with additional descriptions of all the species hitherto named, and of many not before noticed, by Edward Griffith, F.L.S., A.S., \&c and others (E. Griffith, 
429 Greenfield HJ. 2006. Slicing cut marks on animal bones: diagnostics for identifying stone tool

$430 \quad$ type and raw material. Journal of Field Archaeology 31,147-163. (doi:

$431 \quad 10.1179 / 009346906791071972)$

432 Harcourt R, Martins Sequeira AM, Zhang X, Rouquet F, Komatsu K, Heupel M, McMahon CR, 433 Whoriskey FG, Meekan M, Carroll G, Brodie S, Simpfendorfer C, Hindell M, Jonsen I, 434 Costa DP, Block B, Muelbert M, Woodward B, Weise M, Aarestrup K, Biuw M, Boehme L, 435 Bograd SJ, Cazau D, Charrassin JB, Cooke SJ, Cowley P, de Bruyn PJN, Jeanniard du Dot T, Duarte C, Eguíluz VM, Ferreira LC, Fernández-Gracia J, Goetz K, Goto Y, Guinet C, Hammill M, Hays GC, Hazen EL, Hückstädt LA, Huveneers C, Iverson S, Jaaman SA,

Haynes V. 1968. Radiocarbon: analysis of inorganic carbon of fossil bone and enamel. Science 161, 687-688. (doi: 10.1126/science.161.3842.687)

Heller E. 1904. Mammals of the Galapagos Archipelago, exclusive of the Cetacea. Proceedings of the California Academy of Sciences 3, 233-50. 
450 Hindell MA, McMahon CR. 2000. Long distance movement of a southern elephant seal

451 (Mirounga leonina) from Macquarie Island to Peter 1 Øy. Marine Mammal Science 16, 504452 507. (doi: $10.1111 /$ j.1748-7692.2000.tb00944.x)

453 Hindell MA, McMahon CR, Bester MN, Boehme L, Costa D, Fedak MA, Guinet C, 454 Herraiz-Borreguero L, Harcourt RG, Huckstadt L, Kovacs KM. 2016. Circumpolar habitat 455 use in the Southern elephant seal: implications for foraging success and population

457 trajectories. Ecosphere 7, e01213. (doi: 10.1002/ecs2.1213)

Hindell MA. 2018. Elephant seals: Mirounga angustirostris and M. leonina. In Encyclopedia of marine mammals (eds B Würsig, JGM Thewissen, KM Kovacs), pp. 303-307, 3rd ed. San Diego, CA: Academic Press. (doi: 10.1016/b978-0-12-804327-1.00115-1)

Hofman CA, Rick TC, Erlandson JM, Reeder-Myers L, Welch AJ, Buckley M. 2018. Collagen Fingerprinting and the Earliest Marine Mammal Hunting in North America. Scientific reports 8, 1-6. (doi: 10.1038/s41598-018-28224-0)

Johnson DW. 1990 A southern elephant seal (Mirounga leonina Linn.) in the Northern Hemisphere (Sultanate of Oman). Marine Mammal Science 6, 242-243. (doi: 10.1111/j.1748-7692.1990.tb00248.x)

King, JE. 1972. Observations on phocid skulls. In R. J. Harrison, (ed.), Functional anatomy of marine mammals, pp. 81-115, Academic Press, London, New York.

Koch PL, Hall BL, de Bruyn M, Hoelzel AR, Baroni C, Salvatore MC. 2019. Mummified and skeletal southern elephant seals (Mirounga leonina) from the Victoria Land Coast, Ross Sea, Antarctica. Marine Mammal Science 35, 934-956. (doi: 0.1111/mms.12581) 
471 Le Boeuf BJ, Crocker DE, Costa DP, Blackwell SB, Webb PM, Houser DS. 2000. Foraging

472 ecology of Northern elephant seals. Ecological monographs 70, 353-382. (doi:

473 10.1890/0012-9615(2000)070[0353:FEONES]2.0.CO;2)

474 Lesson, R. P. 1826. Voyage autour du monde entrepris par ordre du gouvernement sur la corvette $475 \quad$ La Coquille. Bruxelles :Gregoir, Wouters,1839.

476 Linnaeus, C. 1758. Systema naturae per regna tria naturae, secundum classes, ordines, genera, 477 species, cum characteribus, differentiis, synonymis, locis. Tomus I (in Latin) (10th ed.). 478 Holmiæ: Laurentius Salvius. pp. 37-38.

479 Lucero SO, Gariboldi MC, Bauni V, Meluso JM, Castillo DD, Agnolin FL, Bogan S. 2018. 480 Stranded humpback whale (Megaptera novaeangliae)(Cetacea: Balaenopteridae) in Paraná 481 River Delta, Buenos Aires Province, Argentina. Comments on the occurrence of marine 482 mammals in the La Plata River Basin. Papéis Avulsos de Zoologia 58, 1-8. (doi: $0.11606 / 1807-0205 / 2018.58 .01)$

484 Lyman RL. 1994. Vertebrate taphonomy (Cambridge Manuals in Archaeology). Cambridge: 485 Cambridge University Press. (doi: 10.1017/CBO9781139878302)

486 Lyman RL, Harpole JL, Darwent C, Church R. 2002. Prehistoric occurrence of pinnipeds in the 487 lower Columbia River. Northwestern Naturalist 83, 1-6. (doi: 10.2307/3536507) 488 Magalhães FA, Hassel LB, Venturotti ACV, Siciliano S. 2003. Southern elephant seals 489 (Mirounga leonina) on the coast of Rio de Janeiro State, Brazil. Latin American Journal of Aquatic Mammals 2, 55-56. (doi: 10.5597/lajam00032)

491 Mayorga LF, Hurtado R, Vanstreels R, Bhering R, Junior JR. 2016. A review of the recent 492 records of pinnipeds (Mammalia, Carnivora) on the coast of Espírito Santo state,

493 Brazil. Check List 12, p.1. (doi: 10.15560/12.6.2015) 
494 Mayorga LF, Bhering R, Hurtado R, Vanstreels R. 2017. Recurrent sightings of a Southern

495 elephant seal (Mirounga leonina) on the southeast coast of Brazil, 2012-2017. Latin

496 American Journal of Aquatic Mammals 12, 53-58 (doi: 10.5597/lajam00237)

497 McMahon CR, Bester MN, Burton HR, Hindell MA, Bradshaw CJ. 2005. Population status,

498 trends and a re-examination of the hypotheses explaining the recent declines of the Southern

499 elephant seal Mirounga leonina. Mammal Review 35, 82-100. (doi: 10.1111/j.1365-

$500 \quad 2907.2005 .00055 . x)$

501 Mertz EM, Bester MN. 2011. Vagrant southern elephant seal and human disturbance in Mossel

502 Bay, South Africa. African Journal of Wildlife Research 41, 224-229. (doi:

503 $10.3957 / 056.041 .0211)$

504

Mignucci-Giannoni AA, Odell DK. 2001. Tropical and subtropical records of hooded seals (Cystophora cristata) dispel the myth of extant Caribbean monk seals (Monachus tropicalis). Bulletin of Marine Science 68, 47-58.

Miskelly CM. 2015. Records of three vagrant Antarctic seal species (family Phocidae) from New Zealand: crabeater seal (Lobodon carcinophaga), Weddell seal (Leptonychotes weddellii) and Ross seal (Ommatophoca rossii). New Zealand journal of marine and freshwater research 49, 448-461. (doi: 10.1080/00288330.2015.1080173)

511 Nordquist O. 1899. Beitrag zur kenntniss der isolierten formen der ringelrobbe (Phoca 512 foetida Fabr.). Acta Societatis Pro Fauna et Flora Fennica 15, 1- 43.

513 Olsson IU. 1980. Content of ${ }^{14} \mathrm{C}$ in Marine Mammals from Northern Europe. Radiocarbon 22 , 514 662-675. (doi: 10.1017/s0033822200010031) 
515 Pacheco AS, Silva A, Riascos JM. 2014. The recurring visit of a southern elephant seal

516 (Mirounga leonina L. 1758) to the coast of Antofagasta, northern Chile. Latin American

517 Journal of Aquatic Mammals 9, 168-170. (doi: 10.5597/lajam00184)

518 Páez-Rosas D, Riofrío-Lazo M, Ortega J, de Dios Morales J, Carvajal R, Alava JJ. 2018.

519 Southern elephant seal vagrants in Ecuador: a symptom of La Niña events? Marine

520 Biodiversity Records 11, p.13. (doi: 10.1186/s41200-018-0149-y)

521 Pauketat TR. 2004. Ancient Cahokia and the Mississippians (No. 6). Cambridge University 522 Press.

523 Pinsky ML, Newsome SD, Dickerson BR, Fang Y, Van Tuinen M, Kennett DJ, Ream RR, Hadly

524 EA. 2010. Dispersal provided resilience to range collapse in a marine mammal: insights

525 from the past to inform conservation biology. Molecular Ecology 19, 2418-2429. (doi:

$526 \quad 10.1111 / \mathrm{j} .1365-294 x .2010 .04671 . x)$

527 Prentice G. 1987. Marine shells as wealth items in Mississippian societies. Midcontinental

$528 \quad$ Journal of Archaeology 12, 193-223.

529 Quintana-Rizzo E, Garcia L, López RJ, Tobar-Hurtado S, López-Roulet A. 2017 First record of a

530 Galapagos fur seal (Arctocephalus galapagoensis) in Guatemala. Marine Biodiversity

531 Records 10, p.24. (doi:10.1186/s41200-017-0126-x)

532 Reeves RR, Stewart BS, Clapham PJ, Powell JA. 2002. Guide to the Marine Mammals of the 533 world. National Audobon Society. New York, NY

534 Redwood SD, Felix F. 2018 The most northerly record of a southern elephant seal (Mirounga 535 leonina) in the Pacific Ocean at the island of Taboga, Gulf of Panama, Panama. Aquatic 536 Mammals 44, 13-19. (doi: 10.1578/AM.44.1.2018.13) 
537 Rick TC, DeLong RL, Erlandson JM, Braje TJ, Jones TL, Arnold JE, Des Lauriers MR,

538 Hildebrandt WR, Kennett DJ, Vellanoweth RL, Wake TA. 2011. Where were the Northern 539 elephant seals? Holocene archaeology and biogeography of Mirounga angustirostris. The

$540 \quad$ Holocene 21, 1159-1166. (doi: 10.1177/0959683611400463)

541 Robinson PW, Costa DP, Crocker DE, Gallo-Reynoso JP, Champagne CD, Fowler MA, Goetsch

542 C, Goetz KT, Hassrick JL, Hückstädt LA, Kuhn CE. 2012. Foraging behavior and success

543 of a mesopelagic predator in the northeast Pacific Ocean: insights from a data-rich species,

544 the Northern elephant seal. PLoS ONE 7, e36728. (doi: 10.1371/journal.pone.0036728)

545 Rohland N, Hofreiter M. 2007. Ancient DNA extraction from bones and teeth. Nature Protocols

$$
\text { 2, 1756-1762. (doi: 10.1038/nprot.2007.247) }
$$

Sepúlveda MA, Pérez-Alvarez MJ, López PA, Moraga RO. 2007. Presence and re-sighting of Southern elephant seal, Mirounga leonina (L. 1758), on the north-central coast of Chile. Latin American Journal of Aquatic Mammals 6, 199-202. (doi: 10.5597/lajam00126)

Sepúlveda M, Pavez G, Savaria P, Harrod C, Gomez-Uchida D. 2018. Observación de un elefante marino del sur Mirounga leonina en el Río Toltén, sur de Chile. Revista de biología marina y oceanografía 53, 375-380. (doi: 10.22370/rbmo.2018.53.3.1367)

Shaughnessy PD, Kemper CM, Ling JK. 2012. Records of vagrant phocid seals (family Phocidae) in South Australia. Australian Mammalogy 34, 155-169. (doi:

Stuiver M, Polach HA. 1977. Discussion reporting of ${ }^{14} \mathrm{C}$ data. Radiocarbon 19, 355-363. (doi: $10.1017 / \mathrm{S} 0033822200003672)$ Archaeologist 26, 249-266. (doi: 10.2190/4NR2-8C4H-AWXB-JVPE) 
560 Valastro S, Mott Davis E. 1970. University of Texas at Austin Radiocarbon Dates VIII.

$561 \quad$ Radiocarbon 12, 617-639. (doi: 10.1017/S0033822200008316)

562 Valastro S, Mott Davis E, Varela AG. 1988. University of Texas at Austin Radiocarbon Dates

563 XVI. Radiocarbon 30, 197-253. (doi: 10.1017/s0033822200044131)

564 Weller DW, Schiro AJ, Cockcroft VG, Ding W. 1996. First account of a humpback whale

565 (Megaptera novaeangliae) in Texas waters, with a re-evaluation of historical records from

566 the Gulf of Mexico. Marine Mammal Science 12, 133-137. (doi: 10.1111/j.1748-

$567 \quad$ 7692.1996.tb00311.x)

568 Williams ME, Domning DP. 2004. Pleistocene or post-Pleistocene manatees in the Mississippi

569 and Ohio River valleys. Marine Mammal Science 20, 167-176. (doi: 10.1111/j.1748-

$570 \quad$ 7692.2004.tb01148.x)

571

572 FIGURE CAPTIONS

573

574 Figure 1. USNM 375734 in (a, b) lateral, (c, d) ventral, (e) dorsal view; (f) detail of the maxilla-

575 premaxilla contact in dorsal view. Abbreviations: bz, base of the zygomatic process of the 576 maxilla; if, infraorbital foramen; ip, infraorbital process; $m$, maxilla; $p$, palatal surface of the 577 maxilla; om, orbital margin; mpc, maxilla-premaxilla contact.

578

579 Figure 2. (a) Map showing the extant Mirounga leonina (orange) and M. angustirostris (purple) 580 distribution ranges. Large circles represent their principal breeding colonies. Small circles 581 represent extralimital sightings of M. leonina along the South Atlantic and Pacific oceans (see 582 main text for references). (b) Detail of the geographic location where USNM 375734 was found. 
584 Figure 3. Upper canine measurements for modern Northern and Southern elephant seals and 585 USNM 375734. Data from electronic supplementary table S1. Squares and triangles represent

586 Southern and Northern elephant seals, respectively. Green and gray colors represent females and 587 males, respectively. USNM 375734 is represented by a black dot.

588

589 Figure 4. USNM 375734 in dorsomedial view (a). A magnification of the square is shown in (b). 590 The black arrows heads indicate locations of the potential cut marks described in the text. 


\section{Figure 1}

USNM 375734 in lateral, ventral, and dorsal views.

Figure 1. USNM 375734 in (a, b) lateral, (c, d) ventral, (e) dorsal view; (f) detail of the maxillapremaxilla contact in dorsal view. Abbreviations: bz, base of the zygomatic process of the maxilla; if, infraorbital foramen; ip, infraorbital process; $m$, maxilla; $p$, palatal surface of the maxilla; om, orbital margin; mpc, maxilla-premaxilla contact.
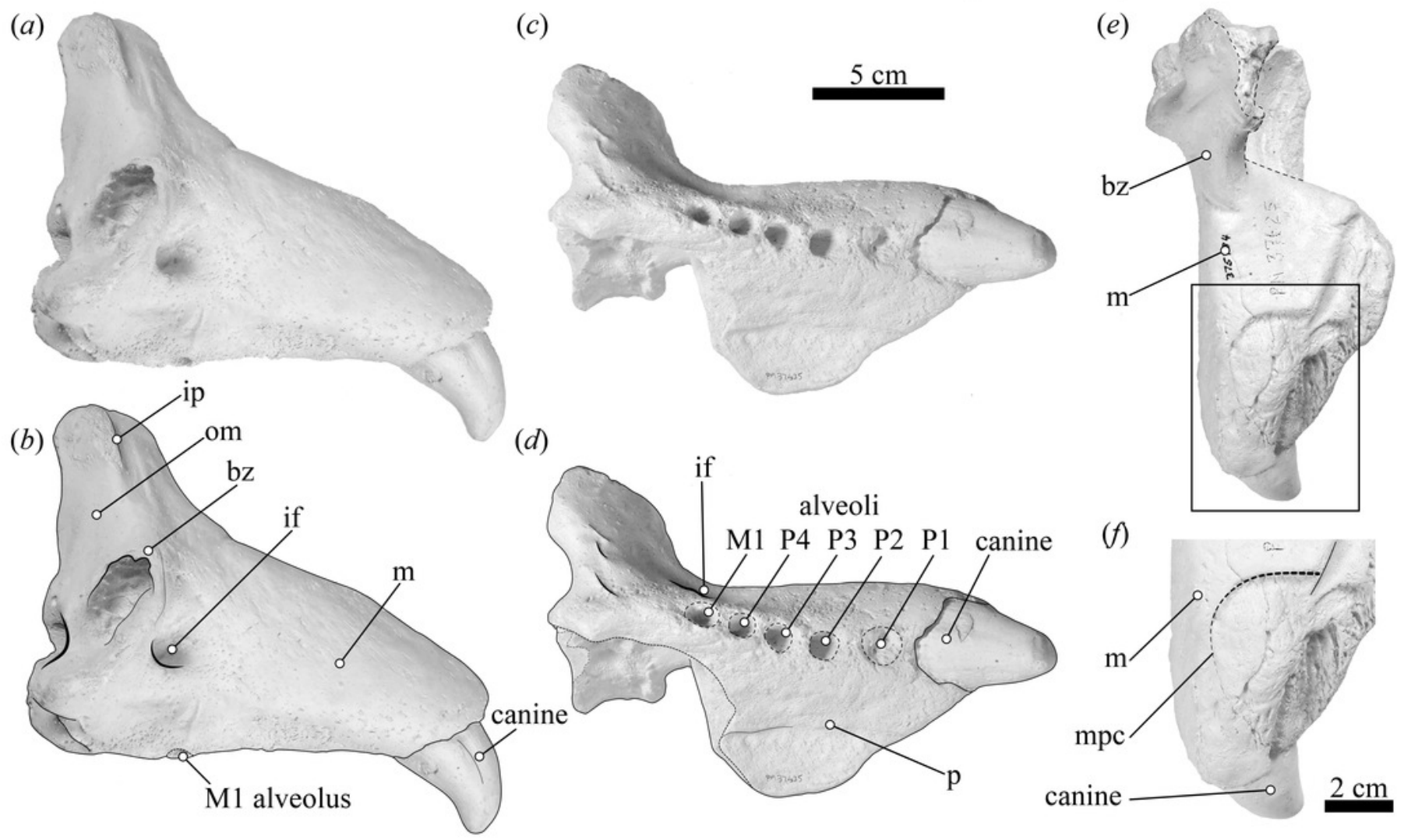


\section{Figure 2}

Map showing the extant elephant seals distribution ranges and detail of the geographic location where USNM 375734 was found.

Figure 2. (a) Map showing the extant Mirounga leonina (orange) and M. angustirostris (purple) distribution ranges. Large circles represent their principal breeding colonies. Small circles represent extralimital sightings of M. leonina along the South Atlantic and Pacific oceans (see electronic supplementary material text S1). (b) Detail of the geographic location where USNM 375734 was found. 


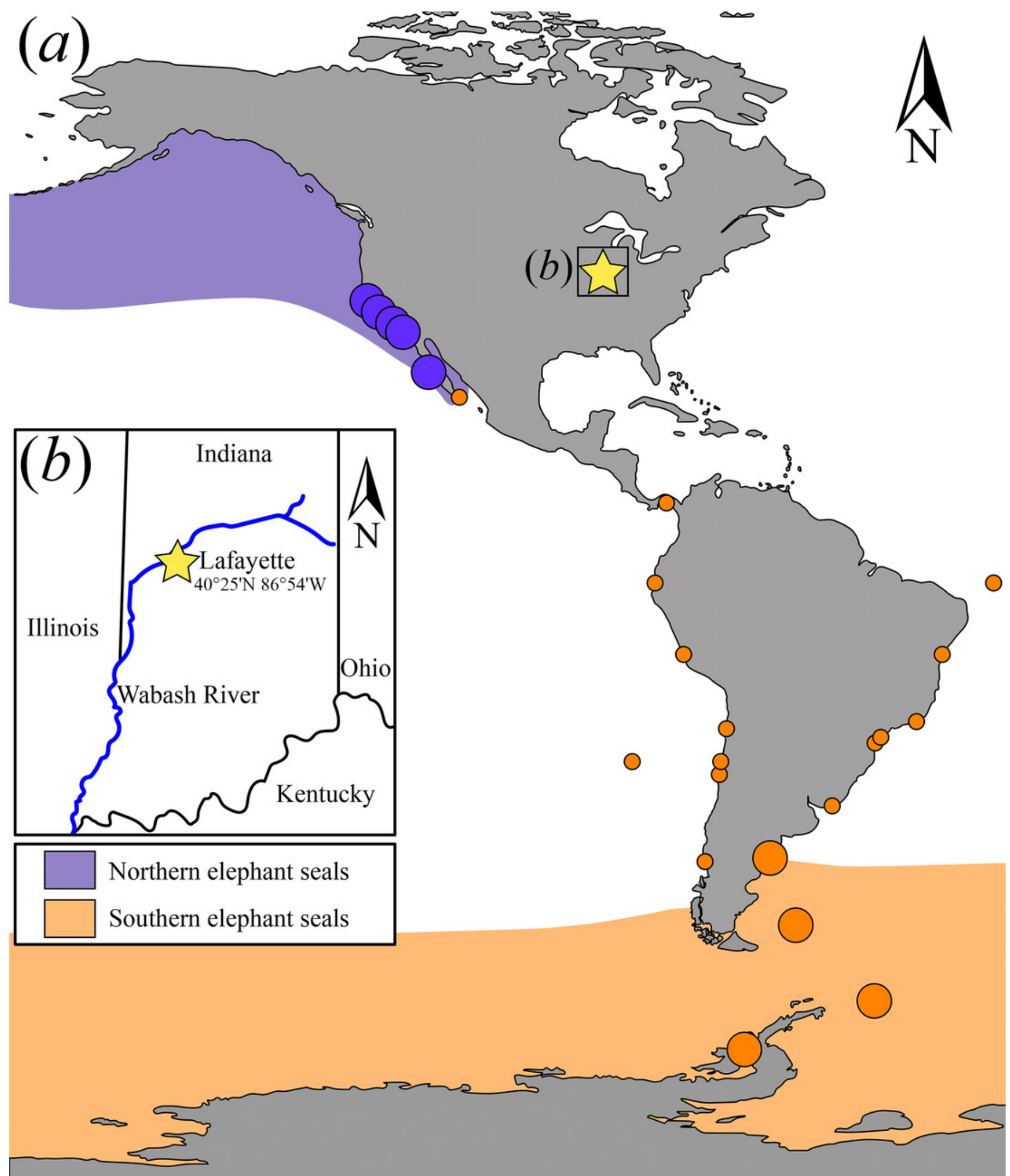




\section{Figure 3}

Canine measurements for modern Northern and Southern elephant seals

Figure 3. Upper canine measurements for modern Northern and Southern elephant seals and USNM 375734. Data from electronic supplementary table S1. Squares and triangles represent Southern and Northern elephant seals, respectively. Green and gray colors represent females and males, respectively. USNM 375734 is represented by a black dot. 


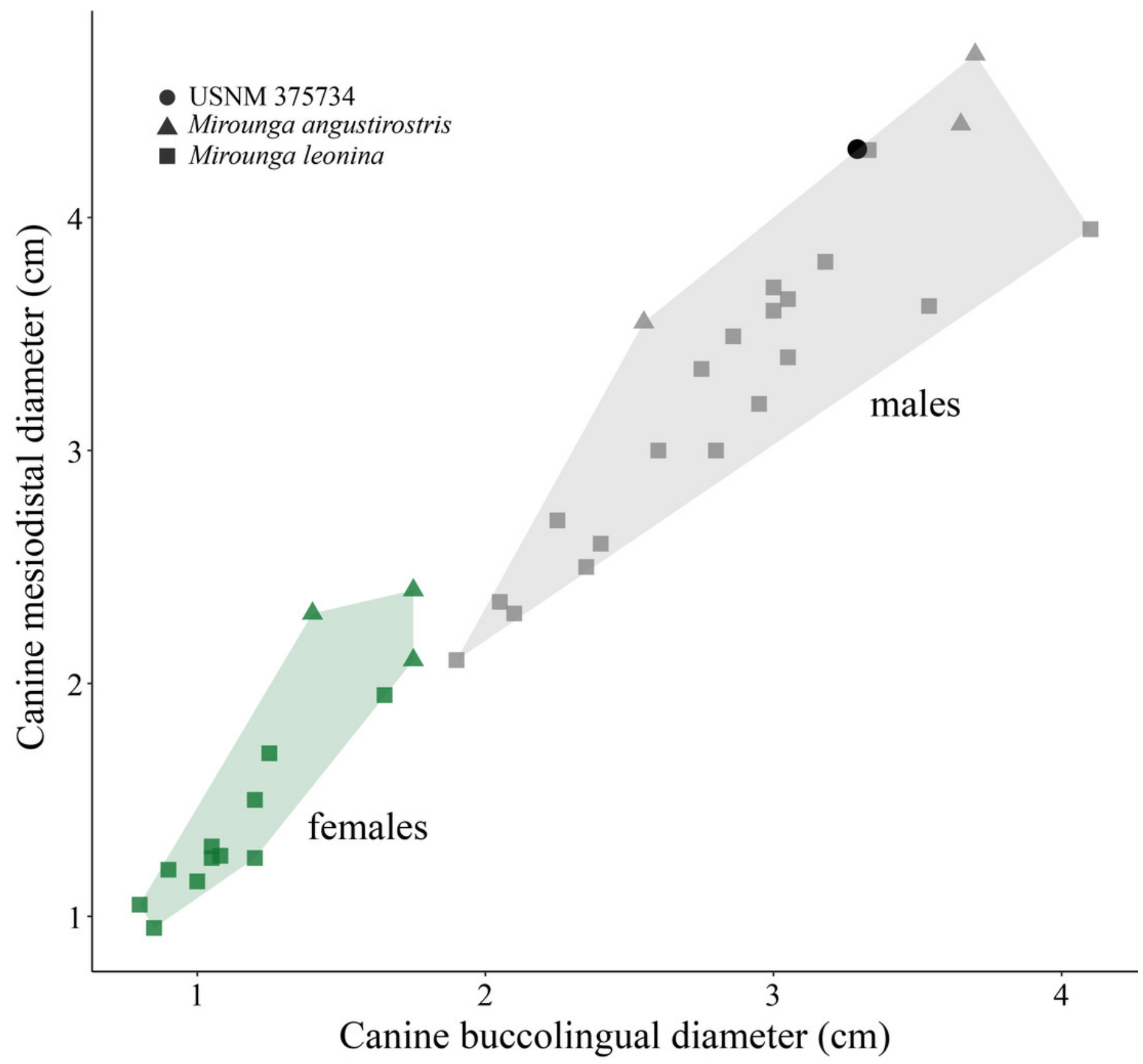


Figure 4

Potential cut marks in USNM 375734

Figure 4. USNM 375734 in dorsomedial view (a). A magnification of the square is shown in (b). The black arrows heads indicate locations of the potential cut marks described in the text.

(a)

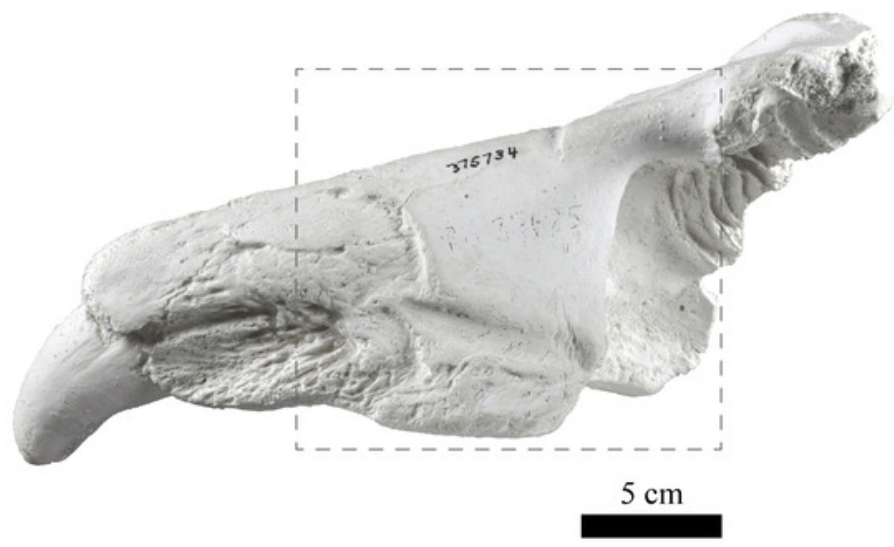

(b)

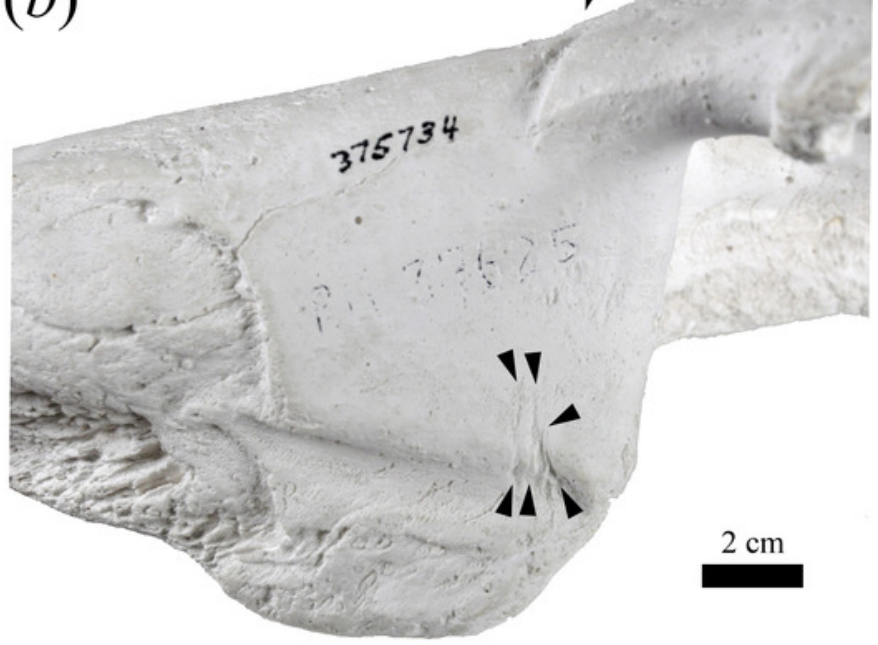


Table $\mathbf{1}$ (on next page)

Table 1. Measurements of USNM 375734

Morphological measurements of USNM 375734 
1 Table 1. Measurements (in cm) of USNM 375734

2

\begin{tabular}{|l|r|}
\hline Maximum length of the maxilla & 18.2 \\
\hline Canine mesiodistal diameter & 4.3 \\
\hline Canine buccolingual diameter & 3.29 \\
\hline P1 alveolus mesiodistal diameter & 1.41 \\
\hline P1 alveolus buccolingual diameter & 1.19 \\
\hline P2 alveolus mesiodistal diameter & 1.36 \\
\hline P2 alveolus buccolingual diameter & 1.02 \\
\hline P3 alveolus mesiodistal diameter & 1.29 \\
\hline P3 alveolus buccolingual diameter & 0.89 \\
\hline P4 alveolus mesiodistal diameter & 1.11 \\
\hline P4 alveolus buccolingual diameter & 0.83 \\
\hline M1 alveolus mesiodistal diameter & 1.18 \\
\hline M1 alveolus buccolingual diameter & 0.76 \\
\hline Length of the tooth row & 8.08 \\
\hline Length of the infraorbital foramen & 1.93 \\
\hline Height of the infraorbital foramen & 1.46 \\
\hline
\end{tabular}

3 